\title{
HYDRODYNAMICS AND BIO-OPTICAL ASSESSMENT OF TWO PRISTINE SUBTROPICAL ESTUARIES IN SOUTHERN BRAZIL
}

\author{
Mauricio Almeida Noernberg ${ }^{1, *}$, Byanka Damian Mizerkowski, \\ Nicole Gabriele Paloschi ${ }^{1}$ and Joaquim Pereira Bento ${ }^{2}$ \\ ${ }^{1}$ Universidade Federal do Paraná \\ (Av. Beira Mar s/n - P.O. Box. 61, 83255-976 Pontal do Paraná, PR, Brasil) \\ ${ }^{2}$ Universidade de Kiel \\ (Christian-Albrechts-Platz 4, 24118 Kiel, Alemanha) \\ *Correspondig author: m.noernberg@ufpr.br
}

http://dx.doi.org/10.1590/S1679-87592014069006204

\begin{abstract}
A B S T R A C T
Measuring small-scale physical processes and how they affect the spatial patterns of sea water's optical constituents plays a key role in understanding the functioning of complex coastal ecosystems such as estuaries. The spatial variations of physical and bio-optical water properties were investigated during one spring tidal cycle in the austral summer, on two transects across the channel of the Medeiros and Itaqui subestuaries. These sub-estuaries are a biosphere reserve, and part of the Paranaguá Estuarine System, located on the Southern Brazilian coast. Both sub-estuaries were classified as Type 1a, wellmixed with low stratification. The salinity variations are in phase with the water level, and the tidal propagation is well represented by a standing wave. The vertical velocity profiles showed little vertical shear, and the intensity of the u-component of the velocity varied semi-diurnally. The upper estuary salt transport was dominated by tidal diffusion in an unstable water column. The optical environment presented a mixed dominance of optically active substances, as indicated by the absorption coefficients of dissolved and particulate matter. The colored dissolved organic matter (CDOM) showed overall conservative behavior and was dominant in light absorption below $550 \mathrm{~nm}$ in the Medeiros, while nonalgal particles play the most important role in light absorption in the Itaqui in the blue absorption band. The phytoplanktonic contribution is prominent in the red domain and increases as a function of saline intrusion. However, due to the influence of freshwater discharge and the re-suspension of bottom sediments induced by physical processes, the concentrations of the optical components in the water column do not generally have any simple relationships between them.
\end{abstract}

\section{RESUMO}

A quantificação de processos de transporte de pequena escala e a compreensão de como eles afetam o padrão espacial dos constituintes ópticos da água são peça chave no funcionamento de um ecossistema costeiro. A variação espacial e local de propriedades físicas e bio-ópticas da água foi analisada durante um ciclo de maré de sizígia do verão austral, bem como as estimativas do transporte advectivo e dispersivo de sal na secção transversal da boca dos subestuários Mederiros e Itaqui. Estes subestuários fazem parte do Sistema Estuarino de Paranaguá, sul do Brasil, e também integram a reserva da biosfera. Ambos os subestuários foram classificados como Tipo $1 \mathrm{a}$, bem misturados com pouca estratificação. As variações da salinidade estão em fase com o nível da água, e a propagação da onda de maré se dá na forma de uma onda estacionária. Os perfis verticais de velocidade mostraram pouco cisalhamento vertical, e a intensidade da componente u de velocidade variou semidiurnamente. $\mathrm{O}$ transporte de sal estuário acima foi dominado pela difusão da maré em uma coluna de água instável. O ambiente óptico apresentou uma dominância mista dos componentes opticamente ativos, como indicado pelos coeficientes de absorção dos materiais dissolvidos e particulados. A matéria orgânica dissolvida colorida (CDOM) apresentou um comportamento conservativo com dominância da luz abaixo de $500 \mathrm{~nm}$ em Medeiros, enquanto que no subestuário Itaqui as partículas não algais foram dominantes na faixa do azul. A contribuição do fitoplâncton é alta na faixa do vermelho e aumenta em função da intrusão salina. Contudo, devido à influência da descarga de água doce e a ressuspensão de sedimentos induzida por processos físicos as concentrações dos componentes ópticos na coluna d'água geralmente não apresentam uma relação simples entre si.

Descriptors: Estuarine circulation, Salt transport, Water quality, Optical classification, Absorption coefficients, Laranjeiras Bay.

Descritores: Circulação estuarina, Transporte de sal, Qualidade da água, Classificação óptica, Coeficiente de absorção, Baía das Laranjeiras. 


\section{INTRODUCTION}

The Paranaguá Estuarine Complex (PEC), located on the Paraná State coast in south-eastern Brazil (lat: $25^{\circ} 30^{\prime} \mathrm{S}$; long: $48^{\circ} 25^{\prime} \mathrm{W}$ ), is a large, interconnected subtropical estuarine system that comprises two main water bodies and a wide variety of intertidal environments, such as mangrove swamps, marshes, and non-vegetated tidal flats (LANA et al., 2000). Fishing and commercial activities together with urban and tourism pressure throughout the PEC make it one of the most economically and ecologically important estuaries on the Brazilian coast.

The two main water bodies of the PEC have similar environmental characteristics but are subject to distinct anthropogenic pressures. The east-west axis is formed essentially by the Paranaguá and Antonina Bays (Fig. 1) and has been influenced by the anthropogenic input of domestic discharges, port and industrial effluents, and intense contamination with sewage near the city of Paranaguá (MARTINS et al., 2010). The north-south axis is formed by Laranjeiras Bay, an Environmental Protection Area of ecological importance. The Laranjeiras Bay catchment area is one of the last preserved Atlantic rainforests of South America and has been protected as a biosphere reserve by the United Nations Educational, Scientific and Cultural Organization (UNESCO) since 1993. The estuary can be classified as pristine, with neither anthropogenic impacts caused by the introduction of oil and its derivates nor any fecal contribution (MARTINS et al., 2012).

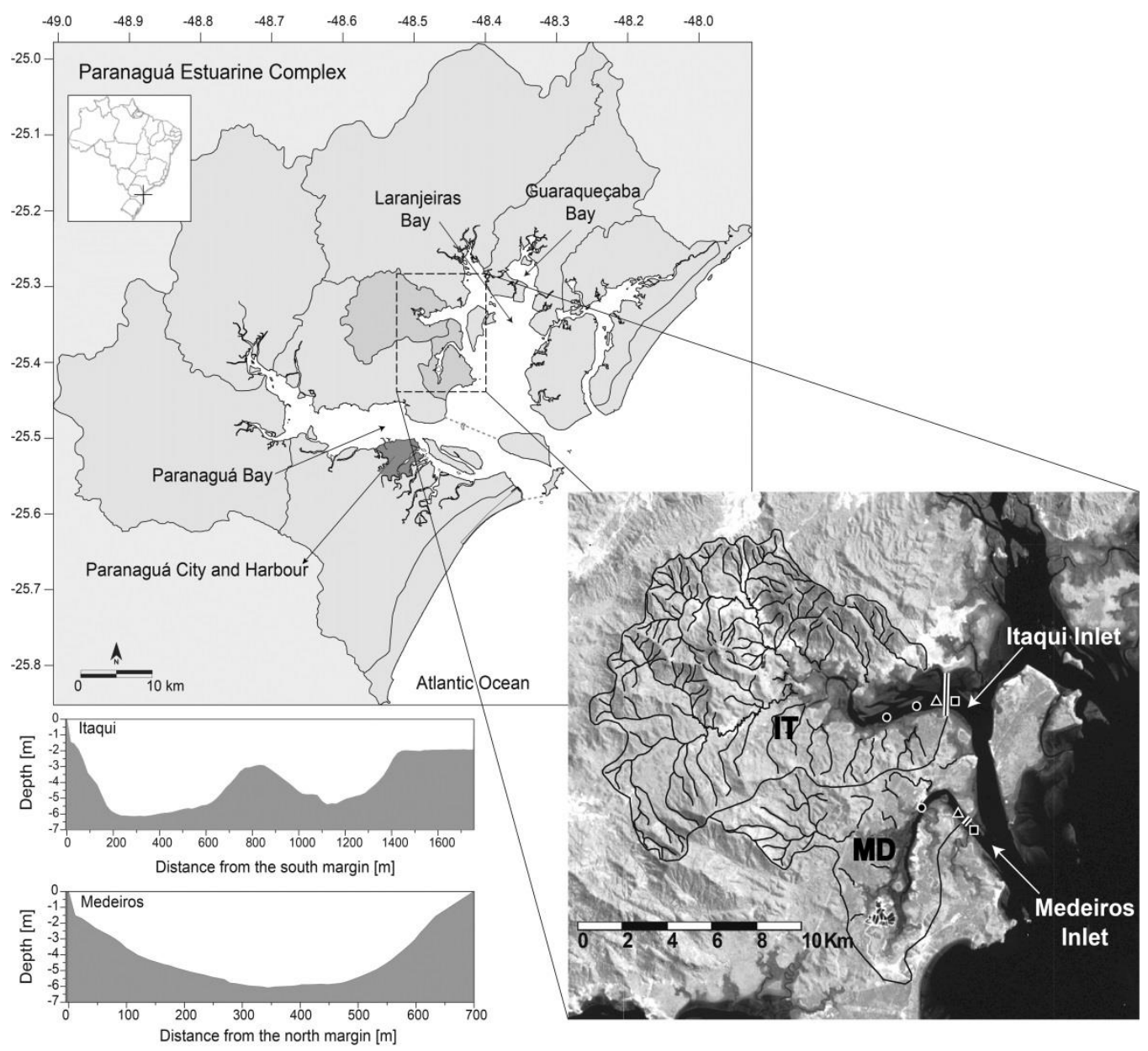

Fig. 1. The Paranaguá Estuarine Complex, composed of Laranjeiras Bay and Paranaguá Bay, and the delimitation of the catchment areas. Paranaguá Harbour, Paranaguá City, Paranaguá Bay, Laranjeiras Bay and Guaraqueçaba Bay are indicated by arrows (upper left). The studied areas - the Medeiros (MD) and Itaqui (IT) inlets - and the sample station (circle), anchor stations (triangle), moored station (square) and transect (line) are shown in detail at right. The morphological features of the cross sections are show at bottom left. 
The PEC region has a subtropical wet climate, with distinct wet and dry seasons. The mean annual rainfall is $2500 \mathrm{~mm}$ (maximum $5300 \mathrm{~mm}$ ), and the mean annual relative humidity is approximately $85 \%$. The mean precipitation during the rainy season (summer: December to March) is more than three times higher than during the dry season (winter). The tidal regime is semidiurnal with diurnal inequalities. Mean neap and spring tidal heights are, respectively, 1.3 and $1.7 \mathrm{~m}$ at the bay mouth and 2.0 and $2.7 \mathrm{~m}$ at Antonina (MARONE and JAMIYANAA, 1997). Stratification and mixing processes in the main channels are controlled primarily by tidal currents and secondarily by freshwater discharge, which causes seasonal variations in the magnitude of vertical salinity stratification. Paranaguá Bay can exhibit highly stratified (summer neap tides), partly mixed (summer spring tides) and well-mixed (winter spring tides) conditions within a single season or fortnight (MANTOVANELLI et al., 2004). Despite its great environmental importance and preservation status, Laranjeiras Bay is under-studied; information on the hydrographic and hydrodynamic characteristics of its sub-estuaries is practically non-existent, or at least unpublished. NOERNBERG et al. (2006) documented the morphological and hydrological characteristics of this region. The main characteristics of the two subestuaries that are the focus of this study are presented in Table 1.

Table 1. Morphological and hydrological characteristics of the Medeiros and Itaqui sub-estuaries (adapted from NOERNBERG et al., 2006).

\begin{tabular}{lll}
\hline \hline & Medeiros & Itaqui \\
\hline Drainage area $\left(\mathrm{km}^{2}\right)$ & 44.6 & 122.8 \\
Drainage density $\left(\right.$ river $\left./ \mathrm{km}^{2}\right)$ & 0.98 & 1.88 \\
Hydraulic gradient & 0.07 & 0.04 \\
Maximum width to length ratio & 0.14 & 0.27 \\
Wetlands area $\left(\mathrm{km}^{2}\right)$ & 9.1 & 8.6 \\
Water body area $\left(\mathrm{km}^{2}\right)$ & 4.12 & 7.74 \\
Tidal flat area $\left(\mathrm{km}^{2}\right)$ & 2.6 & 4.2 \\
Relative tidal flat area $(\%)$ & 63.1 & 54.3 \\
\hline
\end{tabular}

There is increasing interest in describing and assessing the environmental conditions along the north-south axis of the PEC. Environmental damage related to sporadic harmful algae blooms (FERNANDES et al., 2001; MAFRA JR et al., 2006), oil spills and the discharge of polluted effluents by a shrimp farm and small villages has already been observed in the area. These negative impacts are neither quantified nor qualified due to the lack of an environmental monitoring program and the ineffectiveness of management plans for the coastal region of the state of Paraná. Therefore, assessing the environmental setting, such as the hydrodynamics and bio-optical properties, of these pristine estuaries is of the utmost importance to improve the understanding of these complex coastal environments and to develop adequate management strategies for the region.

Quantifying and understanding the natural processes that occur, on a relatively short time scale, in coastal environments such as estuaries, is not only relevant within a scientific perspective, but also crucial for the planning and management of these valuable natural resources. Reliable data are invaluable for decision makers' identification of the reasons for occuring environmental problems (JI, 2008).

The aim of this study is to investigate the spatial and local variations of physical and bio-optical water properties of the two sub-estuaries of the PEC (the Medeiros and the Itaqui). Specific objectives of this study are: $i$ ) the estimation of the advective and dispersive salt transport along fixed transects across the channels of the Medeiros and Itaqui sub-estuaries during a spring tidal cycle; $i i)$ the quantification of the relative contributions of the absorption of phytoplankton $\left(a_{\mathrm{ph}}\right)$, non-algal particles $\left(a_{\mathrm{NAP}}\right)$ and colored dissolved organic matter $\left(a_{\mathrm{CDOM}}\right)$ to the total absorption coefficient. The relationship of these variables to salinity is assessed to investigate the possible use of color images as proxies of water circulation through variations in the salt content.

Our approach was to describe the basic thermohaline, hydrodynamic and bio-optical characteristics of the two sub-estuaries of the PEC, aiming to set the stage for the long-term goal of establishing a physical-biological-geochemical-optical platform combining modelling, remote sensing and in situ observations to guide the management of this coastal ecosystem.

\section{Material ANd Methods}

Surveys were conducted in March, 2012 on the Medeiros sub-estuary (day 05) and the Itaqui subestuary (day 09). Tidal height, current speed and direction, and hydrographic properties were measured by an InterOcean S4-CTD electromagnetic current meter which collected data every fifteen minutes, with a frequency of acquisition of $2 \mathrm{~Hz}$, over one spring tidal cycle at a moored station positioned one meter above bottom at the sub-estuary mouth (Fig. 1). Current velocity profiles were measured hourly along a fixed transect across the mouth of each estuary during a 13-hour tidal cycle, using a boat-mounted $1000 \mathrm{kHz}$ Sontek ADP. The instrument was set up with $0.8 \mathrm{~m}$ bin resolution and 1 minute averaging. 
Between every ADP transect the vertical profiles of hydrographic properties were measured with an anchored Alec CTD, model ASTD. The vertical profiles of hydrographic properties were also measured at hourly intervals at four and three stations, respectively, along each of the sub-estuaries (of the Medeiros and the Itaqui). Water samples from the subsurface (approximately $1 \mathrm{~m}$ depth) were taken at least once during each phase of the tidal cycle (high, ebb, low and flood tide) to determine the concentrations of chlorophyll and particulate suspended matter and the absorption coefficients of dissolved organic and particulate matter.

The hydrographic properties such as the temperature, conductivity and pressure $(T, C$ and $p)$ were converted into salinity $(S)$ and sigma-t $\left(\sigma_{t}\right)$, in accordance with the Practical Salinity Scale (PSS-78) and the International Equation of State of Sea Water (IES-80). The velocity vector was decomposed into axial ( $u$-component) and transverse ( $v$-component) components in accordance with $\mathrm{Oxyz}$, the local referential system, with the origin on the free surface of the water. $\mathrm{O} x$ and $\mathrm{O} y$ were the longitudinal and transversal axes, oriented positively seawards and to the left margin respectively, and the vertical axis, $\mathrm{O} z$, was oriented against gravity acceleration (positive values upward).

Due to the shallowness of both channels' cross-sections (depths between 4.2 and $5.7 \mathrm{~m}$ for the Medeiros and 4.4 and $6.6 \mathrm{~m}$ for the Itaqui at the slack low and high water respectively), the sampling depth (z) was normalised according to KJERFVE (1975) by its dimensionless value $Z=z / h(t)$, where $h(t)$ is the water depth at the sampling time $t$. All the measurements performed at each sub-estuary crosssection were quality controlled, smoothed and interpolated along the water column at intervals of $0.05 \mathrm{Z}$.

The sub-estuaries were classified in accordance with the classical stratification-circulation diagram theoretically derived by HANSEN and RATTRAY (1966), which was also used to calculate the relative contributions of the advective and diffusive processes to the upstream salt transport through its key parameter $(v)$. The advective salt transport components, such as the river discharge, tidal diffusion, Stokes drift, and density currents, were calculated according to a methodology adapted from MIRANDA et al. (2002) on the assumption that the channel was laterally homogeneous.

The stability characteristics of the subestuaries during the spring tidal cycle were analysed using the Richardson layer number $R i_{L}$ (BOWDEN, 1963, 1978), where $h(t)$ and $\Delta \rho_{V}(t)$ are the local depth $(\mathrm{m})$, the bottom density minus the surface density, the mean-depth density $\left(\mathrm{kg} \mathrm{m}^{-3}\right)$ and the mean-depth velocity $\left(\mathrm{m} \mathrm{s}^{-1}\right)$, respectively.
The physical interpretation of the layer Richardson number depends on its magnitude: for $R i_{L}>20$, the water column is highly stable with low vertical mixing; for $R i_{L}<20$, the bottom turbulence causes vertical mixing in the water column; and below the critical value $R i_{L} \sim 2$, turbulent mixing makes the water column unstable (DYER and NEW, 1986).

Water samples were collected during four tidal phases in each sub-estuary (Table 2) using dark plastic bottles that were pre-washed with $10 \% \mathrm{HCl}$, purified water and rinsed with local water before being stored in a refrigerated container. The water samples were stored in dark plastic bottles inside a cooling box until processing that occurred after the sampling campaigns. Due to the lack of logistic infrastructure on the survey platforms, the samples were kept as stable as possible for a maximum of 12 hours before filtration. The samples were filtered in accordance with the methodology described by the NASA protocols (MITCHELL et al., 2002) for the determination of the absorption coefficients of colored dissolved organic matter (CDOM) and particulate matter. Whatman GF/F filters were used to determine the suspended particulate matter and chlorophyll concentrations following the gravimetric and fluorometric methodologies, respectively (STRICKLAND and PARSONS, 1972). Chlorophyll concentrations were determined for the $24 \mathrm{~h}$ acetone $(90 \%)$ extraction sample using a Turner Design Fluorometer (10AU).

Table 2. Bio-optical sampling time, tidal phase and sample name.

\begin{tabular}{llllll}
\hline \hline \multicolumn{3}{c}{ Medeiros } & \multicolumn{3}{c}{ Itaqui } \\
\hline $\begin{array}{l}\text { Local } \\
\text { Time }\end{array}$ & Tide & Reference & $\begin{array}{l}\text { Local } \\
\text { Time }\end{array}$ & Tide & Reference \\
08:23 & Low & M1 & $7: 15$ & Ebb & I1 \\
11:05 & Spring & M2 & $9: 30$ & Low & I2 \\
15:25 & High & M3 & $12: 05$ & Spring & I3 \\
20:10 & Ebb & M4 & $15: 27$ & High & I4 \\
\hline
\end{tabular}

The light absorption coefficient for CDOM was measured in $0.2 \mu \mathrm{m}$ mixed membrane filters that were prewashed for 15 minutes with $5 \% \mathrm{HCl}$ before filtering. The seawater filtering was performed in four steps: initially three successive filtrations of $50 \mathrm{ml}$ to wash the filter and filtering apparatus, followed by a fourth filtration of approximately $400 \mathrm{ml}$, from which $50 \mathrm{ml}$ of the CDOM sample were preserved in an amber glass bottle (prewashed with $10 \% \mathrm{HCl}$ and rinsed 3 times) and $350 \mathrm{ml}$ used in the particulate matter absorption coefficient analysis. After filtration, 
the CDOM absorbance (250-800 nm, $1 \mathrm{~nm}$ step) was measured with a spectrophotometer (Shimadzu UV1601PC) using ultra-filtered distilled water as a blank. The absorbance was transformed into absorption coefficients (dimensions $\mathrm{m}^{-1}$ ) by subtracting the blank, normalising it at $660 \mathrm{~nm}$ (BRICAUD et al., 1981), multiplying it by 2.303 and dividing it by the path length through the spectrophotometer cuvette $(0.1 \mathrm{~m})$.

The absorption coefficients of particulate matter were determined using GF/F glass-fiber filters (Whatman). Different volumes were filtered in dim light, and the filtering apparatus was rinsed with the filtered seawater to gather the retained material into the filter and to eliminate the salt content. The method followed the "quantitative filter technique" described by MITCHELL et al. (2002). First, the absorbance of the total particulate matter $(300-750 \mathrm{~nm}, 1 \mathrm{~nm}$ step) was determined with the spectrophotometer, and the filter was then soaked in hot methanol for 90 minutes to extract all the pigments. This 'bleached' filter was rinsed with the filtered seawater to eliminate the methanol. Finally, the absorbance of the remaining material, termed non-algal particles (NAP or detritus), was measured. The absorbance of the particulate matter and of the NAP were converted into absorption coefficients by using the averaged values between $740-750 \mathrm{~nm}$ as a baseline, subtracting the absorbance of the blank filter, multiplying them by 2.303 , and dividing them by the $\beta$-scaling factor (calculated according to MITCHELL et al., 2002) and the geometric absorption path length (the volume of filtered liquid multiplied by the area of the filter). The difference between the absorption coefficient of the total matter and NAP gave the absorption coefficient of phytoplankton.

\section{Results}

January and March are climatologically the rainiest months (DNM, 1992), but they exhibited lower-than-average rainfall in 2012. In January and March, 2012 the rainfall at Paranaguá was 34.2\% and $86.7 \%$, respectively, lower than the twenty-nine year average (Fig. 2).

\section{Currents and Hydrography}

The bottom salinity variations correlate with tidal height at the bottom moored station, with the maximum salinity occurring close to high water on both the Medeiros and Itaqui sub-estuaries (Figs 3a and $3 \mathrm{~b}$ ). On the Itaqui, an oscillation in salinity occurs close to low water, which is likely associated with the complex transversal bathymetry (Fig. 1).

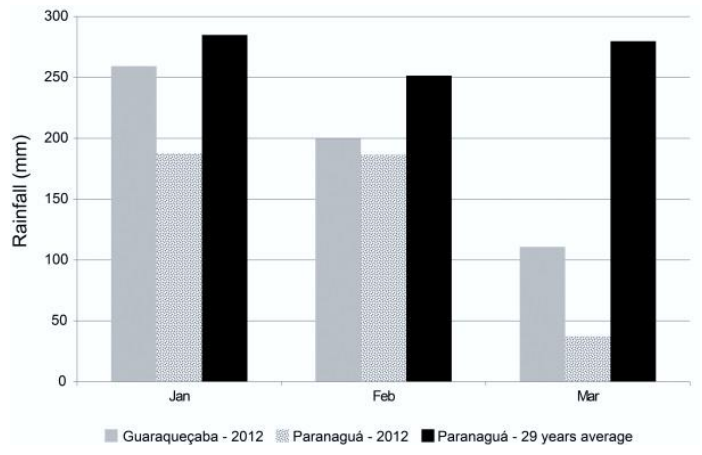

Fig. 2. Climatological rainfall values for Guaraqueçaba, Paranaguá and Paranaguá averaged over the 29-year period between 1961 and 1990.
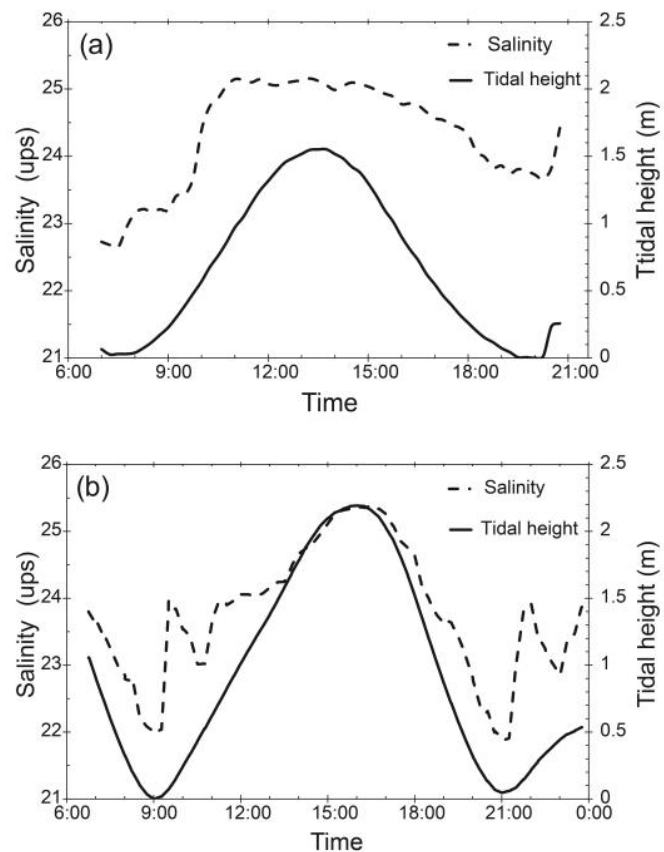

Fig. 3. Time variation of bottom salinity and tidal height at moored station. a) Medeiros and b) Itaqui.

The hourly vertical profiles of the $u$ component of velocity and salinity at the anchor station showed similar patterns over time on both subestuaries (Fig. 4). On the Itaqui, the $u$-component of velocity (Fig. 4a) varied from $-0.41 \mathrm{~m} \mathrm{~s}^{-1}$ (during flooding) to $0.74 \mathrm{~m} \mathrm{~s}^{-1}$ (during ebb); similarly, the ucomponent of velocity varied from $-0.30 \mathrm{~m} \mathrm{~s}^{-1}$ to 0.60 $\mathrm{m} \mathrm{s}^{-1}$ on the Medeiros sub-estuary (Fig. 4b). The velocity measurements at both sites indicate that the shear was high during the ebb phase, and a small asymmetry between up and down-estuary flows was observed. 

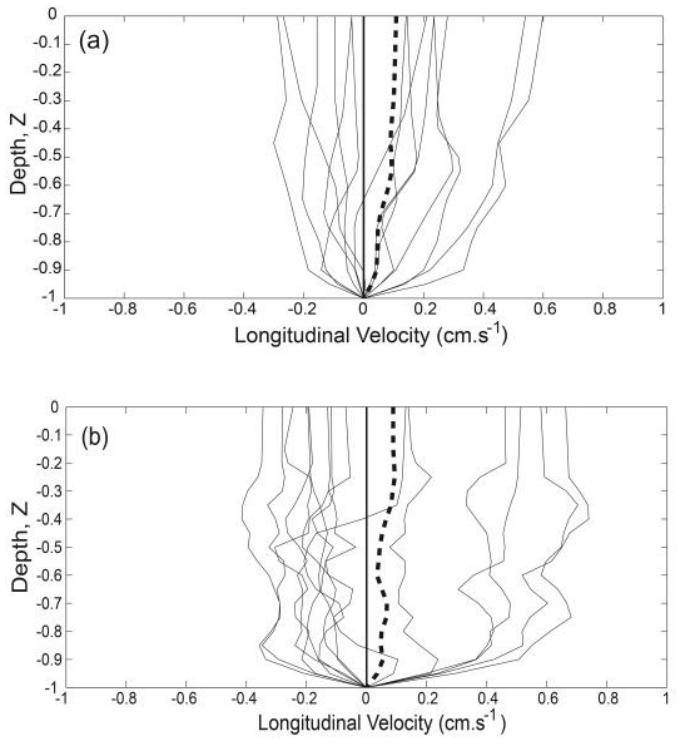

Fig. 4. Time variation of hourly vertical profiles of the $u$ component of velocity at the anchor station at Medeiros (a) and Itaqui (b). $u<0$ and $u>0$ indicates up and down estuary current directions.

The hourly vertical profiles of salinity (Figs. $5 \mathrm{a}$ and $5 \mathrm{~b}$ ) show the salinity variations caused by the advective influence of tidal currents and the background river discharge. On the Medeiros, the average salinity was 23.56 ups at the surface and 24.63 ups at the bottom; on the Itaqui, the average salinity was 21.56 ups at the surface and 23.75 ups at the bottom. Over the tidal cycle water temperatures varied from $28.4^{\circ} \mathrm{C}$ to $30.3^{\circ} \mathrm{C}$ on the Medeiros and $28.6^{\circ} \mathrm{C}$ to $30.2^{\circ} \mathrm{C}$ on the Itaqui, with the highest temperatures occurring during the time of greatest solar radiation. The vertical distribution of temperature presented nearly isothermal conditions with mean variations of $0.7^{\circ} \mathrm{C}$ and $0.5^{\circ} \mathrm{C}$ for the Medeiros and the Itaqui, respectively.

The vertical velocity profiles showed little vertical shear (Fig. 4) in either of the sub-estuaries, except near the bottom as a result of friction. On the Medeiros, the buoyancy was less important in controlling the velocity shear because of the weaker vertical salinity gradients (Fig. 5a). On the Itaqui, the salinity profiles indicate a shallow halocline erosion and intensification (Fig. 5b); the maximum surface and bottom salinities occurring close to high water, when the water column presents some degree of stratification due to river discharge.

The water column stability was evaluated using the Richardson layer number $\left(R i_{L}\right)$. Both subestuaries showed dominance of turbulent flows $\left(R i_{L}<2\right)$ during the full tidal cycle, however on the Itaqui it was possible to observe short periods $(\sim 2$ h) of weak stability $\left(2<R i_{L}<20\right)$ during both low and high tides.
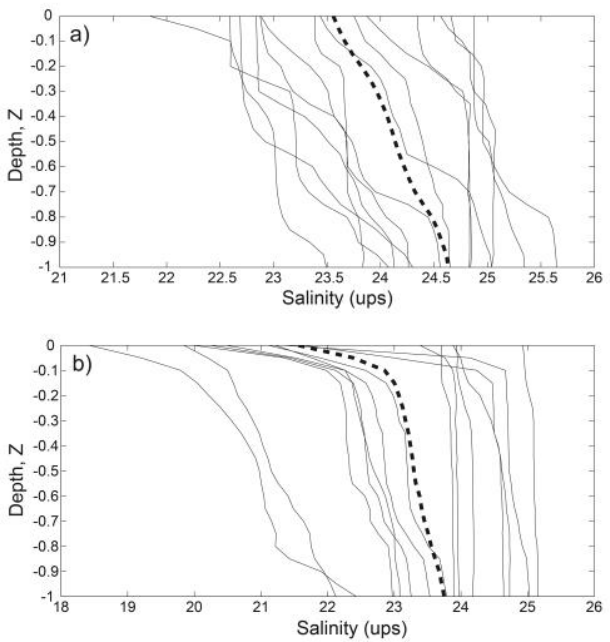

Fig. 5. Time variation of hourly salinity vertical profiles at the anchor station at Medeiros (a) and Itaqui (b).

Salt Transport Components and Estuary Classification

The main residual salt transport components are presented in Table 3. In both sub-estuaries, the main advective component was the river input. The down-estuary salt transport, due to the residual velocity, presented a maximum of $1.72 \mathrm{~kg} \mathrm{~s}^{-1} \mathrm{~m}^{-1}$ in the Medeiros and of $1.84 \mathrm{~kg} \mathrm{~s}^{-1} \mathrm{~m}^{-1}$ in the Itaqui. The Stokes drift was oriented in the same direction as the river input (down-estuary) with a magnitude of transport of $0.20 \mathrm{~kg} \mathrm{~s}^{-1} \mathrm{~m}^{-1}$ in the Medeiros and of 0.44 $\mathrm{kg} \mathrm{s}^{-1} \mathrm{~m}^{-1}$ in the Itaqui. The remaining salt transport components, such as the tidal diffusion and the baroclinic forcing were found to be negligible. Moreover, the total salt transport during the tidal cycle was $1.96 \mathrm{~kg} \mathrm{~s}^{-1} \mathrm{~m}^{-1}$ and $2.32 \mathrm{~kg} \mathrm{~s}^{-1} \mathrm{~m}^{-1}$ in the Medeiros and the Itaqui, respectively.

Table 3. Main advective salinity transport components per unit width for the spring tidal cycle in the Medeiros and Itaqui sub-estuaries.

\begin{tabular}{lll}
\hline \hline Components & Medeiros & Itaqui \\
\hline Residual velocity (river input) & 1.72 & 1.84 \\
Stokes drift & 0.20 & 0.44 \\
Tidal diffusion & 0.04 & 0.04 \\
Baroclinic forcing & 0.00 & 0.00 \\
$\mathrm{~S}$ & 1.96 & 2.32 \\
\hline units in $\mathrm{kg} \mathrm{m}^{-1} \mathrm{~s}^{-1}$ & &
\end{tabular}

The stratification $\left(\mathrm{p}_{\mathrm{e}}\right)$ and circulation parameters $\left(p_{c}\right)$ were calculated using the timeaveraged profiles of salinity and of the $u$-component of velocity. A description of these parameters can be 
found in HANSEN and RATTRAY (1966). These parameters are shown in the composite stratificationcirculation diagram for the Medeiros and Itaqui subestuaries (Fig. 6). Both sub-estuaries were classified as Type 1a (well-mixed and low stratification), with $v=0.99$. The sub-estuaries were characterised by a unidirectional time-averaged velocity profile.

Bio-Optical Parameters: Chlorophyll and Suspended Particulate Matter Concentrations and Dissolved and Particulate Absorption Coefficients

Chlorophyll- $a$ concentrations ranged from 6 to $12 \mathrm{mg} \cdot \mathrm{m}^{-3}$, while suspended particulate matter (SPM) varied over one order of magnitude. A maximum of $22.3 \mathrm{~g} \cdot \mathrm{m}^{-3}$ of SPM was recorded at the first low tide sampling from the Medeiros (sample M1), along with a maximum of $12.6 \mathrm{mg} \cdot \mathrm{m}^{-3}$ of chlorophyll- $a$, whereas SPM remained under $2 \mathrm{~g} \cdot \mathrm{m}^{-3}$ during the rest of the tidal cycle at this location. Maxima chlorophyll $\left(11.1 \mathrm{mg} \cdot \mathrm{m}^{-3}\right)$ and SPM $(13.2$ $\mathrm{g} \cdot \mathrm{m}^{-3}$ ) values were also concomitantly measured during ebb tide in the Itaqui sub-estuary (sample I1), however the concentrations here had less variation than that observed in the Medeiros. Average concentrations of the bio-optical parameters, absorption coefficients and exponential slopes are presented in Table 4.

The CDOM spectral absorption coefficients $\left(a_{\mathrm{CDOM}}(\lambda)\right)$ followed exponential functions, with higher $a_{\mathrm{CDOM}}(\lambda)$ observed in the Medeiros sub-estuary and during low tide at both sub-estuaries. Figure 7 presents $a_{\mathrm{CDOM}}(\lambda)$ and the average exponential slope $\left(S_{\mathrm{CDOM}}\right)$ calculated following BABIN et al. (2003) for absorption coefficients at $350-500 \mathrm{~nm}$. The dominance of the conservative behaviour of CDOM is supported by the strong correlation between $a_{\mathrm{CDOM}}(\lambda)$, at 250$450 \mathrm{~nm}$, and salinity at the two locations (Fig. 8). The spectral slope ratio $\mathrm{S}_{\mathrm{R}}$ (defined as $S_{(275-295)} \backslash S_{(350-400)}$ ), used here to indicate the source of the dissolved organic matter (DOM), according to the relation between $a_{\mathrm{CDOM}}(\lambda)$ and the molecular weight of DOM (HELMS et al., 2008), showed little variation from its average of 0.95 (standard deviation 0.03 ) for both subestuaries. The high correlation between $a_{\mathrm{CDOM}}(\lambda)$ and salinity together with $S_{R}<1$ provide strong indications that terrestrial inputs dominate the dissolved organic pool in the Medeiros and Itaqui sub-estuaries.

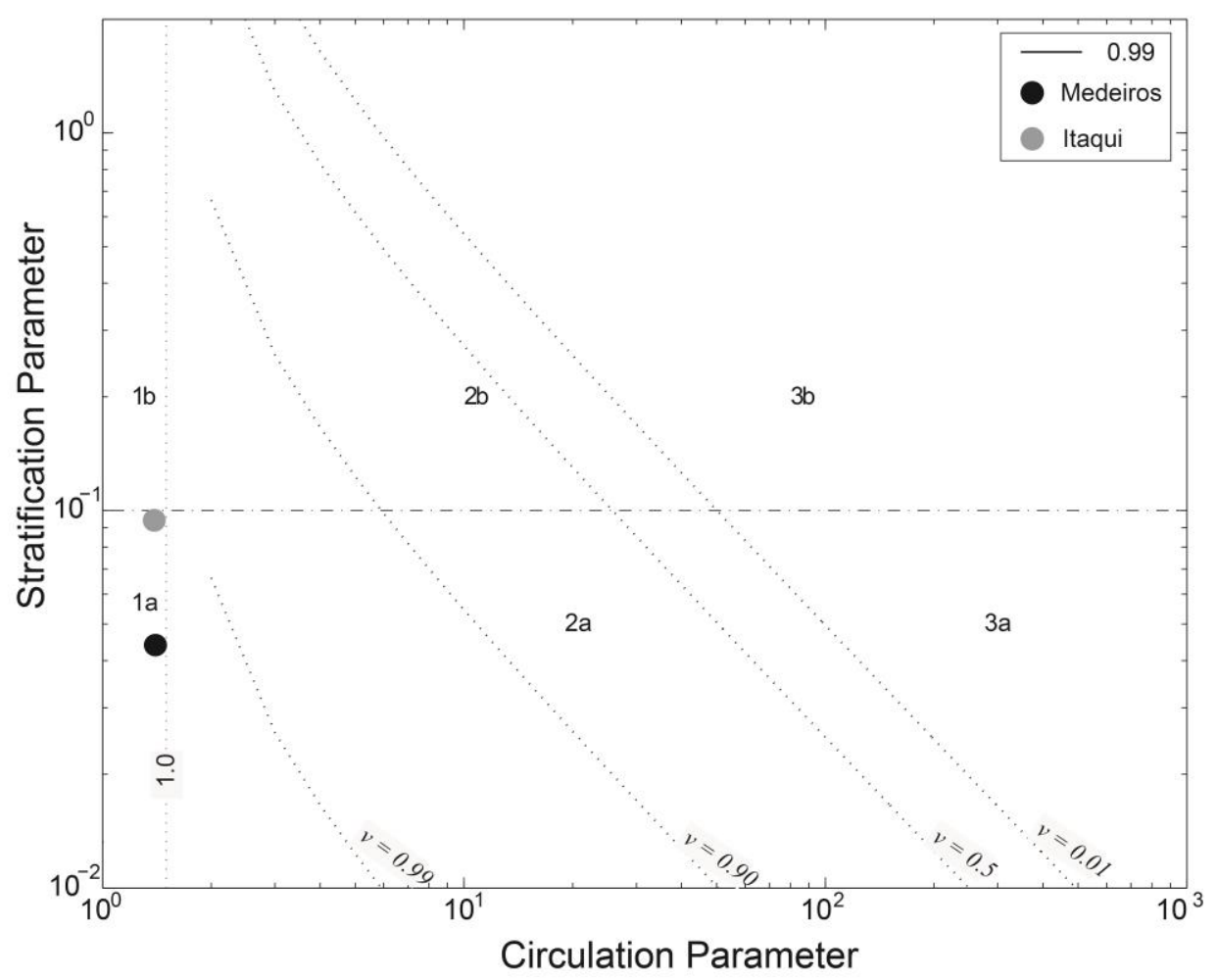

Fig. 6. Stratification-circulation diagram. Medeiros (black circle) and Itaqui (grey circle) classified as Type 1a. 
Table 4. Average values and standard deviations of bio-optical parameters recorded in the Medeiros and Itaqui sub-estuaries. Bracketed values give the observed ranges (minima and maxima).

\begin{tabular}{|c|c|c|}
\hline Variable & Medeiros & Itaqui \\
\hline $\begin{array}{l}\text { [Chla }] \\
\left(\mathrm{mg} \cdot \mathrm{m}^{-3}\right)\end{array}$ & $\begin{array}{l}8.5 \pm 2.8 \\
{[6.7-12.6]}\end{array}$ & $\begin{array}{l}9.1 \pm 1.9 \\
{[7.0-11.1]}\end{array}$ \\
\hline $\begin{array}{l}\text { [SPM] } \\
\left(\mathrm{g} \cdot \mathrm{m}^{-3}\right)\end{array}$ & $\begin{array}{c}1.4 \pm 0.4^{*} \\
{[1.1-1.8]}\end{array}$ & $\begin{array}{l}8.0 \pm 5.0 \\
{[1.9-13.2]}\end{array}$ \\
\hline$a_{\text {СDOM }}(443)$ & $\begin{array}{l}0.498 \pm 0.146 \\
{[0.355-0.652]}\end{array}$ & $\begin{array}{l}0.352 \pm 0.077 \\
{[0.279-0.456]}\end{array}$ \\
\hline$S_{\text {CDOM (350-550) }}$ & $\begin{array}{l}0.0171 \pm 0.0009 \\
{[0.0164-0.0183]}\end{array}$ & $\begin{array}{l}0.0181 \pm 0.001 \\
{[0.0166-0.0187]}\end{array}$ \\
\hline$S_{\mathbf{R}(275-295: 350-400)}$ & $\begin{array}{l}0.94 \pm 0.03 \\
{[0.91-0.97]}\end{array}$ & $\begin{array}{l}0.97 \pm 0.05 \\
{[0.92-1.03]}\end{array}$ \\
\hline$a_{\mathrm{NAP}}(443)$ & $\begin{array}{l}0.316 \pm 0.056 \\
{[0.253-0.387]}\end{array}$ & $\begin{array}{l}0.569 \pm 0.332 \\
{[0.269-0.884]}\end{array}$ \\
\hline$S_{\mathrm{NAP}(380-730)} * *$ & $\begin{array}{l}0.0130 \pm 0.0005 \\
{[0.0126-0.0137]}\end{array}$ & $\begin{array}{l}0.0128 \pm 0.0006 \\
{[0.0123-0.0137]}\end{array}$ \\
\hline$a_{\mathrm{Ph}}(443)$ & $\begin{array}{l}0.233 \pm 0.016 \\
{[0.213-0.249]}\end{array}$ & $\begin{array}{l}0.173 \pm 0.043 \\
{[0.122-0.216]}\end{array}$ \\
\hline$a_{\mathrm{Ph}}^{*}(443)$ & $\begin{array}{l}0.030 \pm 0.008 \\
{[0.017-0.036]}\end{array}$ & $\begin{array}{l}0.019 \pm 0.001 \\
{[0.017-0.020]}\end{array}$ \\
\hline$a_{\mathrm{Ph}}(675)$ & $\begin{array}{l}0.099 \pm 0.006 \\
{[0.093-0.106]}\end{array}$ & $\begin{array}{l}0.101 \pm 0.022 \\
{[0.077-0.124]}\end{array}$ \\
\hline
\end{tabular}

*Outlier of $22.4 \mathrm{~g} \cdot \mathrm{m}^{-3}$ excluded. ** Exponential slope calculated following Babin et al. (2003) using the absorption coefficients between $380-730 \mathrm{~nm}$ but excluding $400-480 \mathrm{~nm}$ and $620-710 \mathrm{~nm}$.
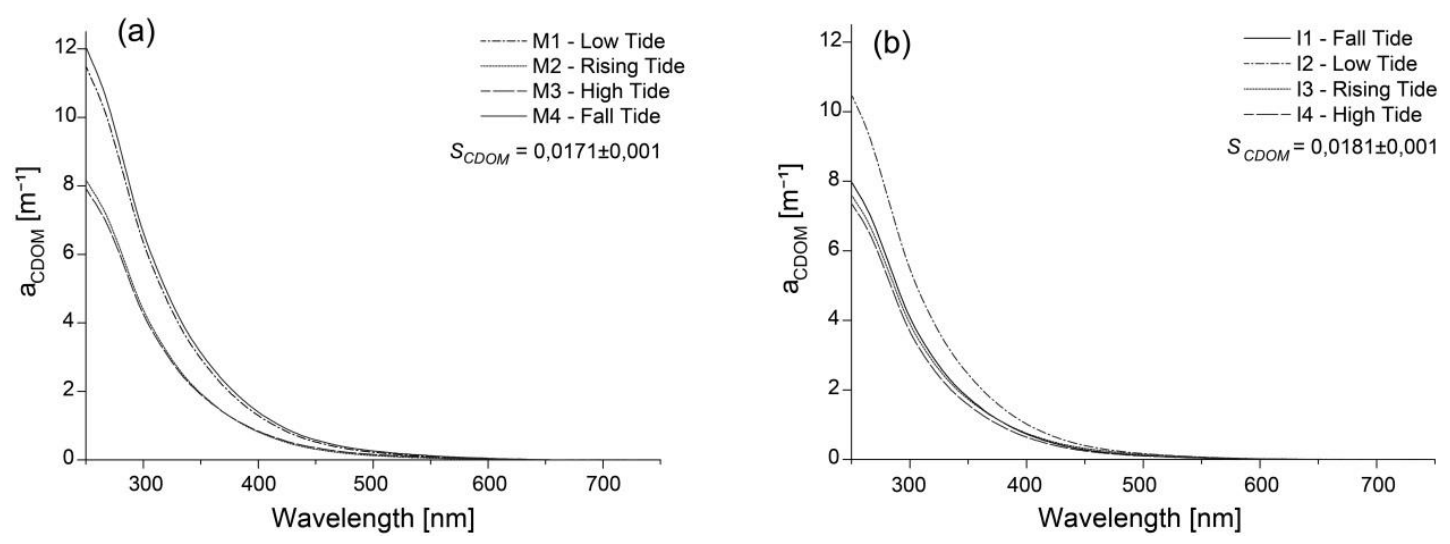

Fig. 7. Time variation of hourly vertical profiles of the $u$-component of velocity at the anchor station at Medeiros (a) and Itaqui (b). $u<0$ and $u>0$ indicates up and down estuary current directions. 


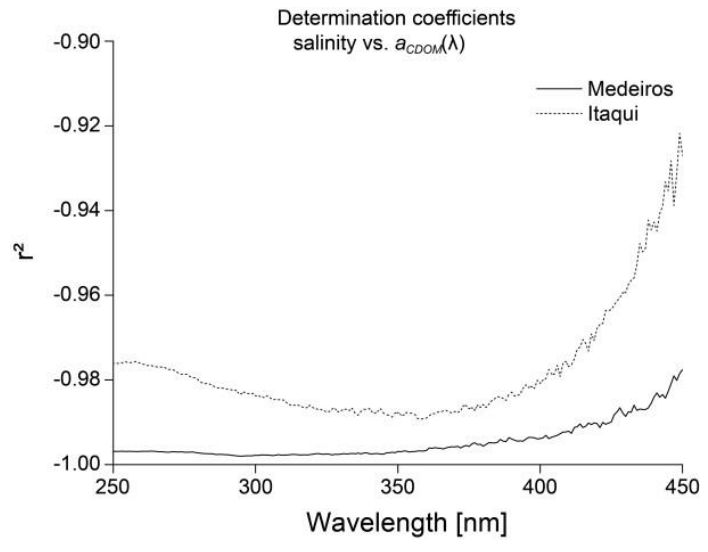

Fig. 8. Determination coefficients $\left(r^{2}\right)$ of the correlations between $a_{\mathrm{CDOM}}(\lambda)$ and salinity for each wavelength at the Medeiros (full line) and Itaqui (dotted line) inlets along the 250-450 $\mathrm{nm}$ range.

The particulate matter absorption coefficient $a_{\mathrm{p}}(\lambda)$ combines the effects of phytoplankton $\left(a_{\mathrm{ph}}\right)$ and remaining non-algal particles $\left(a_{\mathrm{NAP}}\right)$ on light attenuation within the water column. NAP is a mixture of inorganic material and living or non-living heterotrophic organisms, while the contribution of phytoplankton can be distinguished mainly by its photosynthetic pigment signatures (especially chlorophyll- $a$ ). The absorption spectra of the particulate matter in the Medeiros and Itaqui sub-estuaries (Fig. 9) showed similar features overall, with the exception of the ebb- and low-tide phases in the Itaqui sub-estuary. These two tidal phases were characterised by high values of $a_{\mathrm{p}}(\lambda)$, mainly due to an increase in the NAP contribution. The NAP absorption coefficients showed an exponential signature along the visible domain, with $S_{\mathrm{NAP}}$ varying between a maximum of $0.0137 \mathrm{~nm}^{-1}$ during flooding tide in the Medeiros and high tide in the Itaqui and a minimum of $0.0123 \mathrm{~nm}^{-1}$ at low tide in the Itaqui. These values were calculated from the slope of the exponential fit from 380 to $730 \mathrm{~nm}$, excluding the 400-480 nm and 620-710 nm bands, following Babin et al., 2003. Absorption by NAP was predominantly by particles at $443 \mathrm{~nm}$ in both sub-estuaries (Fig. 10). In the Itaqui the contribution of detritus to light attenuation reached maxima of $80 \%$ and $87 \%$ of $a_{\mathrm{p}}(\lambda)$ during ebb and low tides, respectively, whereas maxima relative contribution of phytoplankton to $a_{\mathrm{p}}(\lambda)$ accounted for only $50 \%$.

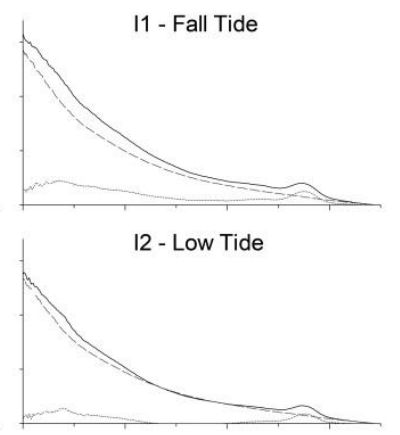

13 - Rising Tide
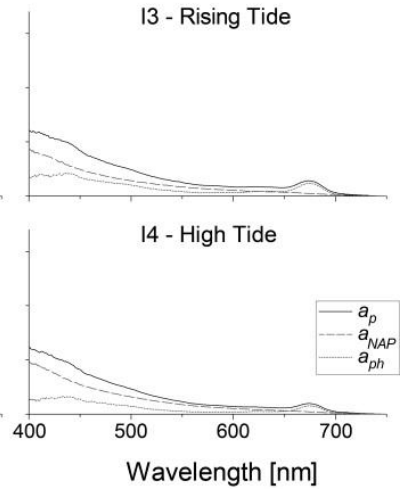

Fig. 9. Particle absorption coefficients $a_{\mathrm{p}}(\lambda)$ (black full line) and the relative contributions of the non-algal particles $a_{\mathrm{NAP}}(\lambda)$ (dotted grey line) and phytoplankton $a_{\mathrm{Ph}}(\lambda)$ (full grey line) for each tidal phase in the Medeiros (left) and Itaqui (right) inlets. 


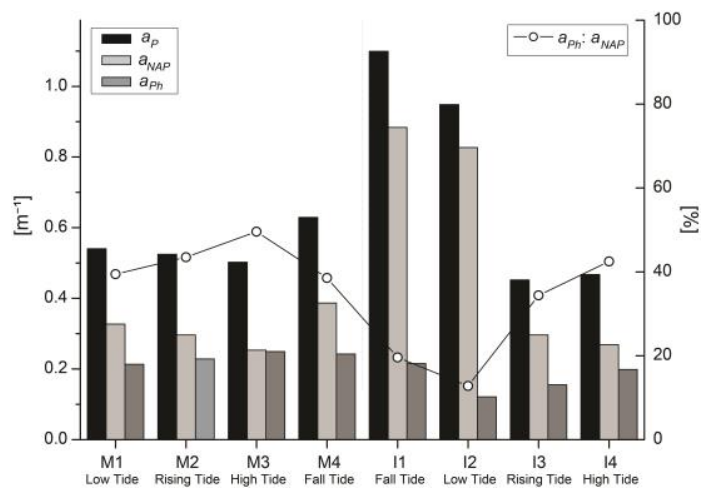

Fig. 10. The relative contributions of $a_{\mathrm{NAP}}(\lambda)$ (light grey columns) and $a_{\mathrm{Ph}}(\lambda)$ (dark grey columns) to $a_{\mathrm{p}}(\lambda)$ (black columns) at $443 \mathrm{~nm}$, and the ratio $(\%)$ of $a_{\mathrm{Ph}}(\lambda)$ to $a_{\mathrm{p}}(\lambda)$ during tidal phases at the Medeiros and Itaqui inlets.

The spectral signatures of chlorophyll- $a$ near $443 \mathrm{~nm}$ and $675 \mathrm{~nm}$ are clearly to be observed along the absorption profiles of phytoplankton from both sub-estuaries (Fig. 11). A shoulder can be seen at approximately 625-635 nm (Fig. 11). Strong positive correlations between $a_{\mathrm{Ph}}(443)$ and chlorophyll

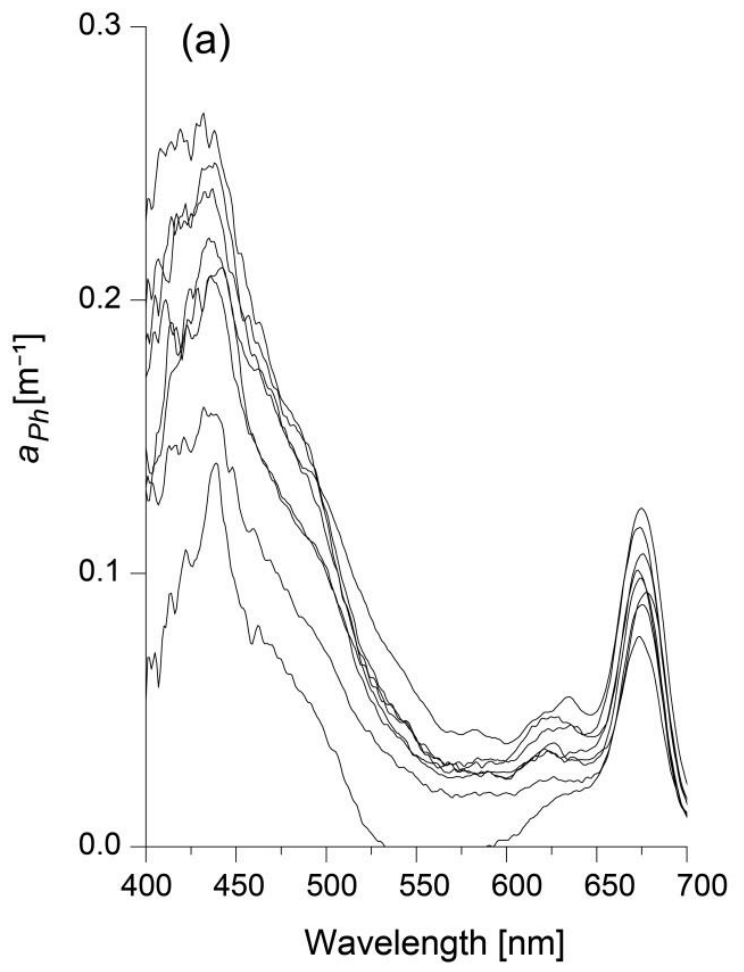

concentration $\left(\mathrm{r}^{2}=0.99\right)$ and between $a_{\mathrm{NAP}}(443)$ and the concentration of SPM $\left(r^{2}=0.94\right)$ were found in the Itaqui, while an inverse correlation between $a_{\mathrm{Ph}}(443)$ and chlorophyll concentration $\left(\mathrm{r}^{2}=-0.86\right)$ was found in the Medeiros. Even though this inverse relationship is highlighted, it is important to note that the small dispersion of four chlorophyll and absorption records may not be enough to characterize a consistent situation. The maxima SPM concentration recorded in Sample M1 masked the positive relationship with $a_{\mathrm{NAP}}(443)$ that is evidenced when the SPM outliers are excluded from the fit $\left(r^{2}=0.99\right)$. Still, the elevated NAP contribution to absorption in water is related to lower salinities; the tidal intrusion can also be related to a higher phytoplanktonic contribution to $a_{\mathrm{p}}(443)$. The specific phytoplankton absorption coefficient $\left(a_{\mathrm{Ph}}^{*}\right.$ at $\left.443 \mathrm{~nm}\right)$ ranged from a minimum of $0.017 \mathrm{~m}^{2} \cdot \mathrm{mg}^{-1}$ for the Itaqui to a maximum of 0.036 in the Medeiros sub-estuary.

The ternary diagrams (Fig. 12) indicate a shift from CDOM and NAP dominance at $443 \mathrm{~nm}$ and $555 \mathrm{~nm}$ to phytoplankton at $675 \mathrm{~nm}$. It is possible to verify that CDOM dominated the absorption in the Medeiros sub-estuary at smaller wavelengths, whereas the NAP contribution is more evident at Itaqui.

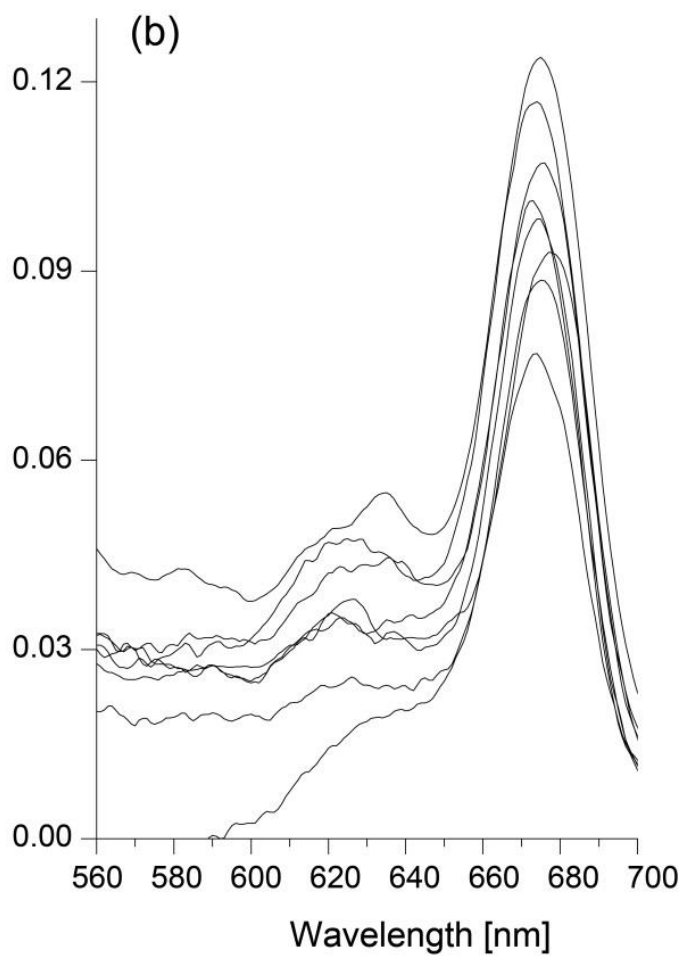

Fig. 11. Phytoplankton absorption coefficients in the $400-750 \mathrm{~nm}$ range (a) and a detail of the 560-750 nm range (b) that shows shoulders at $625-635 \mathrm{~nm}$. 


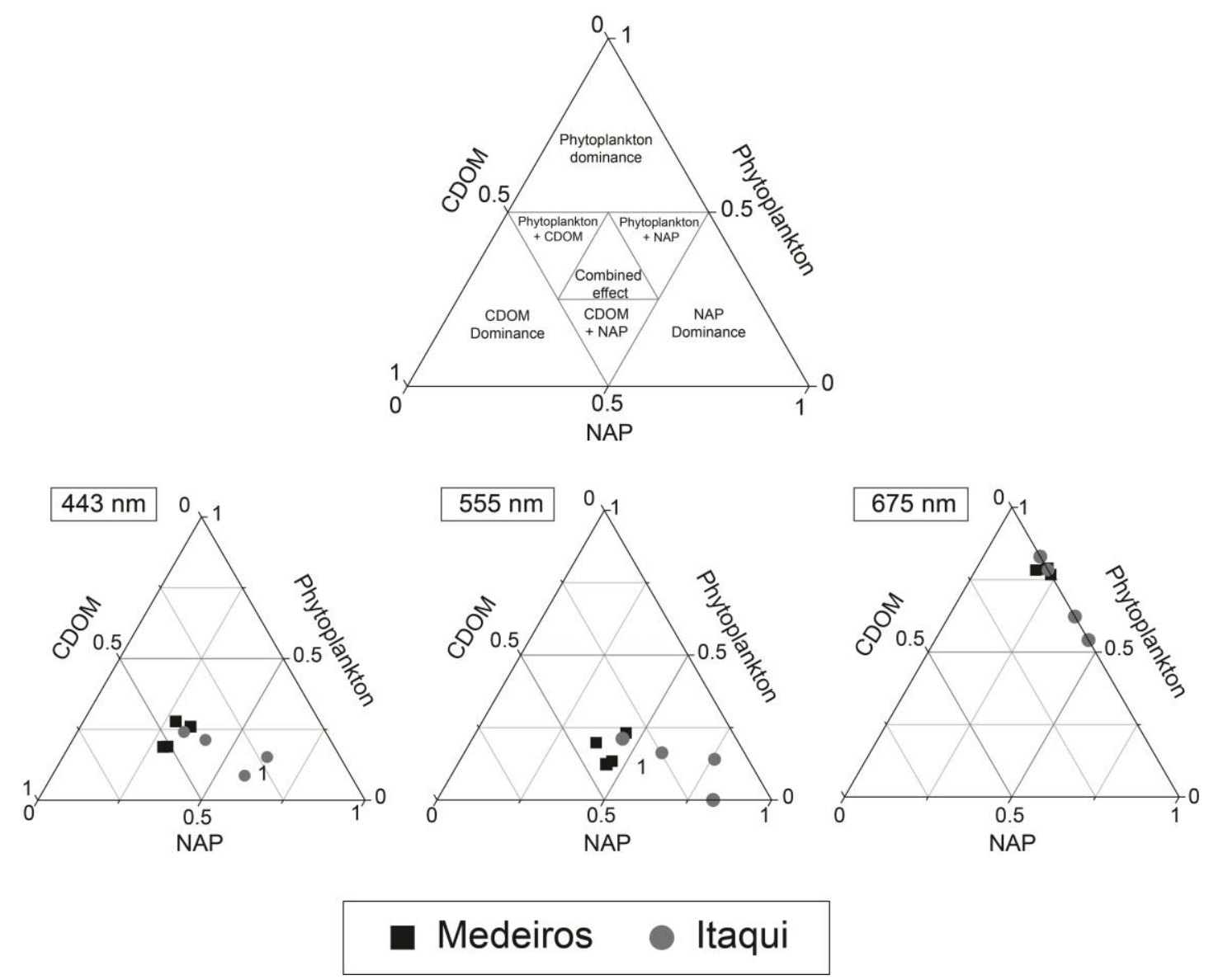

Fig. 12. Ternary diagrams showing the relative contributions of NAP, phytoplankton and CDOM (based on Prieur and Sathyendranath, 1981) at $443 \mathrm{~nm}, 555 \mathrm{~nm}$ and $675 \mathrm{~nm}$ for the Medeiros (black squares) and Itaqui (grey circles) inlets.

\section{DisCUSSION}

Observations of physical and bio-optical properties of the estuarine water column, obtained during the spring tidal cycles for the Medeiros and Itaqui sub-estuaries at the PEC, were planned for March, a season of climatologically wet conditions. The surveys were performed in March 2012, a year when the austral summer, especially March, was around 30\% drier than normal. Both sub-estuaries were well-mixed with low stratification (Type 1a) during the surveys, with $v=0.99$. The larger river, the Itaqui, has a drainage area three times greater than and a drainage density twice that of the Medeiros, and in normal (wet) summer conditions, is likely to present a partially mixed, Type 2 , classification, as observed at Paranaguá Bay by MANTOVANELLI et al. (2004) and at Bertioga (SP) by MIRANDA et al., (1998).
Salinity variations measured at a moored station were in phase with water level variations, with maximum salinity occurring at high water. The observed zero lag between salinity peaks, maximum $\mathrm{ebb}$ and flood velocities ( $u$-component), and water level variations indicate that the tidal propagation is a standing wave.

The vertical velocity profiles showed little shear, except near the bottom as a result of friction. The intensity of the $u$-component of velocity varied semi-diurnally. The up-estuary salt transport was dominated by tidal diffusion. The variation of the Richardson number over time at both sub-estuaries was always below the critical number $\left(\mathrm{R} i_{L}<2\right)$, indicating unstable water column conditions during most of the tidal cycle.

Measuring small-scale physical processes and how they affect the spatial patterns of optical constituents is fundamental for the understanding of the functioning of a coastal ecosystem. Due to the 
influence of freshwater discharge and re-suspension of bottom sediments induced by physical processes, the concentrations of the optical components in the water column generally do not have any simple relationship with bio-optical variables. In some estuaries with higher levels of turbidity the seasonal pattern of absorption and scattering coefficients is driven primarily by changes in the particulate matter of biogenic and mineral origin (GALLEGOS et al., 2005). Distinct scenarios can occur in coastal waters with strong tidal currents, shallow water and important freshwater inputs, such as the English Channel, where meteorology is the main factor driving the bio-optical properties of the water column. The winter period is characterized by the strong dominance of CDOM absorption over the particulate matter, while during the spring-summer period the phytoplankton and CDOM provide a similar contribution (VANTREPOTTE et al., 2007).

The results evidenced the relative contributions of CDOM and the particulate matter, represented by the non-algal particles and the phytoplankton, to light attenuation in the water column. It is clear that the reflectance signal, as observed in other coastal areas (BABIN et al., 2003; STUART et al., 2004; GALLEGOS, 2005; XI et al., 2012; LE et al., 2013), is affected by the complex behaviour of these optically active substances in the study area. Mixed dominances, especially for CDOM and NAP at $443 \mathrm{~nm}$, limit the use of the two-type water type classification model (Cases 1 and 2) commonly used for estuarine regions, such as these study sites. Combining in situ radiometric, bio-optical and biogeochemical measurements can be useful for defining a more comprehensive classification for each specific bio-optical environment, as proposed by VANTREPOTTE et al. (2012).

The terrestrial source of CDOM is likely to be the vast mangrove belts bordering the entire PEC, which strongly suggests that it may be possible to use the optical estimation of CDOM (from the water color) as a proxy for the salinity (XIE et al., 2012, and references therein). Relationships between salinity and $a_{\mathrm{NAP}}(\lambda)$, especially in the $400-600 \mathrm{~nm}$ band, suggest that the suspension of detritus results from both continental inputs (run-off) and tidal fluxes in shallow waters. The phytoplanktonic community, which relies on mesotrophy (chlorophyll concentrations between 5 and $20 \mathrm{mg} \cdot \mathrm{m}^{-3}$, according with the classification of BRICKER et al., 2003), seems to be better developed in higher salinity conditions $(>20)$, which are related to the intrusion of saline waters into the sub-estuaries. The signature of pigments that are believed to be responsible for variations along the phytoplankton absorption spectra, i.e., the shoulders registered at the 625-630 nm band, can be associated with a chlorophyll- $c$ signature (BIDIGARE et al., 1989), indicating the predominance of large diatoms, which are associated with the low $a_{\mathrm{Ph}}^{*}$ observed in the area (BRICAUD et al., 2004). This result indicates a strong influence of the packaging effect, which may be better explained for the area of the PEC by combining spectral analysis of the phytoplankton absorption with the determination of community composition and density, through the use of microscopy and pigment analysis techniques such as High-performace Liquid Chromatography (HPLC). Because the shoulders at $630 \mathrm{~nm}$ black also be associated with phycocyanin, which is an indicator of cyanobacteria (MISHRA et al., 2009), the use of specific pigment band ratios can determine the species composition through the water color and is therefore an important tool for monitoring harmful algae blooms.

Both sub-estuaries presented quite similar behaviour in their hydrographic and hydrodynamic characteristics, with a greater salt transport in the Itaqui due to its larger drainage basin. Despite the few measurements of absorption available, our findings show that the typical typology of complex Case 2 water can be applied to these sub-estuaries. The narrower Medeiros sub-estuary is characterised by higher CDOM influence at the maximum blue absorption, whereas stronger dilution and hydrodynamics with saline waters seem to lead to detritus dominance in the light absorption in the Itaqui sub-estuary. In both systems, saline intrusion is responsible for increasing the phytoplanktonic contribution to the absorption coefficients, especially in the red domain.

Combining the information provided by the in situ observations with bio-optical measurements raises the possibility of determining the spatial patterns of the water circulation in these sub-estuaries using water color images. For instance, despite the high levels of turbulence predominant in these two sub-estuaries, the circulation of water can be described in terms of salinity variations. If any of the optically active substances show conservative behaviour and a strong correlation to salinity, the forecast of tidal-induced patterns of water exchange can be estimated from water color images. Overall, the description of bio-optical properties (using color images) complements the baseline description of these sub-estuaries, and increases the potential for future applications, such as the development/improvement of regional hydrodynamic models.

Overall, the present study brings together an important, albeit limited, baseline description of the hydrodynamics and bio-optical characteristics of two subtropical sub-estuaries, contributing to a better understanding of the influence of forcing mechanisms to the main circulation patterns in such a complex coastal ecosystem that sustains key economic activities in the region. 


\section{ACKNOWLEDGEMENTS}

We are grateful to the Conselho Nacional de Desenvolvimento Científico e Tecnológico (CNPq) for the Research Productivity (308432/2010-0) and PIBIC fellowships awarded to the authors. We are also grateful to the Coordenação de Aperfeiçoamento de Pessoal de Nível Superior (CAPES) for their support of the Project "A Interface Continente Oceano nas Regiões Costeiras e Estuarinas: Estrutura, Processos, Manejo e Sustentabilidade" (Ciências do Mar - 09/2009) and for the postdoctoral fellowship award. The authors would like to acknowledge the kind field assistance of Felipe W. do Carmo, Phellipe Couto and Douglas D. Nemes. We thank the Biogeochemistry Lab. of the Center of Marine Studies and Dr. Eunice da Costa Machado for the use of its facilities. The main equipment used was acquired with the incentives of Brazilian law (Lei 8010 and Portaria MCT/MF 445/98). We would like to thank the anonymous referee for the helpful comments.

\section{REFERENCES}

BABIN, M.; STRAMSKI, D.; FERRARI, G. M.; CLAUSTRE, H.; BRICAUD, A.; OBOLENSKY, G.; HOEPFFNER, N. Variantions in the light absorption coefficients of phytoplankton, nonalgal particles, and dissolved organic matter in coastal waters around Europe. J. Geophys. Res. 108(C7): 1-20, 2003.

BIDIGARE, R. R.; SCHOFIELD, O.; PREZELIN, B. B. Influence of zeaxanthin on quantum yield of photosynthesis of Synechococcus clone WH7803 (DC2). Mar. Ecol. Progr. Ser. 56: 177-188, 1989.

BOWDEN, K. F. The mixing processes in a tidal estuary. Int. J. Air Wat. Poll. 7(4-5):343-356, 1963.

BOWDEN, K. F. Mixing Processes in Estuaries. In: Estuarine Transport Processes, ed. B. Kjerfve. Belle W. Baruch Library In Marine Science, No. 7, University of South Carolina Press, Columbia, S.C., 1978. p. 11-36.

BRICAUD, A.; MOREL, A.; PRIEUR, L. Absorption by dissolved organic matter of the sea (yellow substance) in the UV and visible domains. Limnol. Oceanogr. 26(1): 43-53, 1981.

BRICAUD, A.; CLAUSTRE, H.; RAS, J.; OUBELKHEIR, K. (2004). Natural variability of phytoplankton absorption in oceanic waters: influence of the size structure of algal populations. J. Geophys. Res., 109(C11010): 1-12, 2004. doi:10.1029/2004JC002419.

BRICKER, S. B.; FERREIRA, J. G.; SIMAS, T. An integrated methodology for assessment of estuarine trophic status. Ecol. Model. 169: 39-60, 2003.

DYER, K. R.; NEW, A. L. Intermittency in estuarine mixing. In: Estuarine Variability, ed. D.A. Wolfe, Academic Press, Orlando, Fla, 1986. p. 321-339.

DNM. Normais climatológicas (1961-1990). Ministério da Agricultura e Reforma Agrária. Departamento Nacional de Meteorologia, Brasília, 1992. 84 p.
FERNANDES, L. F.; ZEHNDER-ALVES, L.; BASSFELD, J. C. The recently established diatom Conscinodiscus wailesii (Coscinodiscales, Bacillariophyta) in Brazilian waters. I: Remarks on morphology and distribution. Phycol. Res., 49: 89-96, 2001.

GALLEGOS, C. L. Optical water quality of a blackwater river estuary: the Lower St. Johns River, Florida, USA. Estuar. Coast. Shelf Sci. 63: 57-72, 2005.

GALLEGOS, C. L.; JORDAN, T. E.; HINES, A. H.; WELLER, D. E. Temporal variability of optical properties in a shallow, eutrophic estuary: Seasonal and interannual variability. Estuar. Coast. Shelf Sci. 64(23): 156-170, 2005.

HANSEN, D. V.; RATTRAY, M Jr. New dimensions in estuary classification. Limnol. Oceanogr. 11(3):319326, 1966.

HELMS, J. R.; STUBBINS, A.; RITCHIE, J. D.; MINOR, E. C.; KIEBER, D.; MOPPER, K. Absorption spectral slopes and slope ratios as indicators of molecular weight, source, and photobleaching of chromophoric dissolved organic matter. Limnol. Oceanogr. 53(3):955-969, 2008.

JI, Z. Hydrodynamics and water quality: modeling rivers, lakes, and estuaries. John Wiley \& Sons, Inc., Hoboken, New Jersey, 2008. 676 p.

KJERFVE, B. Velocity averaging in estuaries characterized by a large tidal range to depth ratio. Estuar. Coast. Mar. Sci. 3:311-323, 1975.

LE, C.; HU, C.; ENGLISH, D.; CANNIZZARO, J.; CHEN, Z.; KOVACH, C.; ANASTASIOU, C. J.; ZHAO, J.; CARDER, K. L. Inherent and apparent optical properties of the complex estuarine waters of Tampa Bay: What controls light? Estuar. Coast. Shelf Sci. 117: 54-69, 2013.

MAFRA JUNIOR, L. L.; FERNANDES, L. F.; PROENÇA, L. A. O. Harmful algae and toxins in Paranaguá Bay, Brazil: Bases for monitoring. Braz. J. Oceanogr. 54(1/2):107-121, 2006.

MANTOVANELLI, A.; MARONE, E.; da SILVA, E. T.; LAUTERT, L. F. C.; KLINGENFUSS, M. S.; PRATA, V. P.; NOERNBERG, M. A.; KNOPPERS, A. M.; ANGULO, R. J. Combined tidal velocity and duration asymmetries as a determinant of water transport and residual flow in Paranaguá Bay estuary. Estuar. Coast. Shelf Sci. 59:523-537, 2004.

MARONE, E.; JAMIYANAA, D. Tidal characteristics and a numerical model for the M2 tide at the Estuarine Complex of the Bay of Paranaguá, Paraná, Brazil. Nerítica 11(1/2):95-107, 1997.

MARTINS, C. C.; BÍCEGO, M. C.; FIGUEIRA, R. C. L.; ANGELlI, J. L. F.; COMBI, T.; GALlICE, W. C.; MANSUR, A. V.; NARDES, E.; ROCHA, M. L.; WISNIESKI, E.; CESCHIM, L. M. M.; RIBEIRO, A. P. Multi-molecular markers and metals as tracers of organic matter inputs and contamination status from an Environmental Protection Area in the SW Atlantic (Laranjeiras Bay, Brazil). Sci. Total Environ. 417418:158-168, 2012.

MARTINS, C. C.; BRAUN, J. A. F.; SEYFFERT, B. H.; MACHADO, E. C.; FILLMANN, G. Anthropogenic organic matter inputs indicated by sedimentary fecal steroids in a large South American tropical estuary (Paranaguá estuarine system, Brazil). Mar. Pollut. Bull., 60(11):2137-2143, 2010. 
MIRANDA, L. B.; CASTRO, B. M; KJERFVE, B. Circulation and mixing in the Bertioga Channel (SP, Brazil) due to tidal forcing. Estuaries 21(2):204-214, 1998.

MIRANDA, L. B.; CASTRO, B. M.; KJERFVE, B. Princípios de Oceanografia Física de Estuários. (Acadêmica 42) S Paulo, EDUSP, 2002. 424 p.

MISHRA, S.; MISHRA, D. R.; SCHLUCHTER, W. M. Novel algorithm for predicting phycocyanin concentrations in cyanobacteria: A proximal hyperspectral remote sensing approach. Remote Sensing 1: 758-775, 2009.

MITCHELL, G. B.; KAHRU, M.; WIELAND, J.; STRAMSKA, M. Determination of Spectral Absorption Coefficients of Particles, Dissolved Material and Phytoplankton for Discrete Water Samples. In: Ocean Optics Protocols for Satellite Ocean Color Sensor Validation, Revision 3, Part II, NASA - Goddard Space Flight Center, Greenbelt, EUA, Chapter 15, 2002. p. 231-257.

NOERNBERG, M.A.; LAUTERT, L. F. C.; ARAÚJO, A. D.; MARONE, E.; ANGELOTTI, R.; NETTO JR, J. P. B.; KRUG, L. A. Remote sensing and GIS integration for modeling the Paranaguá Estuarine Complex -Brazil. J. Coastal Res. SI39:1627-1631, 2006.

PRIEUR, L.; SATHYENDRANATH, S. An optical classification of coastal and oceanic waters based on the specific spectral absorption curves of phytoplankton pigments, dissolved organic matter, and other particulate materials. Limnol. Oceanogr. 26(4): 671-689, 1981.

STRICKLAND, J. D. H.; PARSONS, T. R. A practical handbook of seawater analysis. In: Bulletin of the Fisheries Research Board of Canada 167, $2^{\text {nd }}$ ed., 1972. p. $71-80$.
STUART, V.; ULLOA, O.; ALARCÓN, G.; SATHYENDRANATH, S.; MAJOR, H.; HEAD, E.J.H.; PLATT, T. Bio-optical characteristics of phytoplankton populations in the upwelling system off the coast of Chile. Rev. Chil. Hist. Nat. 77: 87-105, 2004.

VANTREPOTTE, V.; LOISEL, H.; DESSAILY, D.; MÉRIAUX, X. Optical classification of contrasted coastal waters. Remote Sens. Environ. 123: 306-323, 2012.

VANTREPOTTE, V.; BRUNET, C.; MÉRIAUX, X.; LÉCUYER, E.; VELLUCCI, V.; SANTER, R. Biooptical properties of coastal waters in the Eastern English Channel. Estuar. Coast. Shelf Sci. 72(1-2): 201-212, 2007.

XIE, H.; AUBRY, C.; BÉlANGER, S.; SONG, G. The dynamics of absorption coefficients of CDOM and particles in the St. Lawrence estuarine system: Biogeochemical and physical implications. Mar. Chem. 128-129: 44-56, 2012.

(Manuscript received 24 September 2013; revised 19 July 2014; accepted 24 July 2014) 